\title{
Association between Herpes Simplex Type 1 Virus Infection and Bell's Palsy
}

\author{
Islam M M ${ }^{* 1}$, Sarkar $\mathbf{S}^{2}$, Das P C $\mathbf{C}^{1}$, Rahman $\mathbf{T}^{3}$, Sazib SMF $^{1}$ \\ ${ }^{I}$ Department of Neurology, ShaheedSuhawardy Medical College Hospital, Dhaka \\ ${ }^{2}$ Department of Neurosurgery, ShaheedSuhrawardy Medical College Hospital, Dhaka \\ ${ }^{3}$ Department of Neurology, Chittagong Medical College Hospital, Chittagong
}

*Corresponding Author: Dr. Mohammad Mohitul Islam, Assistant Professor, Department of Neurology, ShaheedSuhrawardy Medical College, Dhaka.Email: dr.mohitul@yahoo.com

\section{Abstract}

Background: Idiopathic facial paralysis is one of the commonest conditions in neurological practice.

Objective: The purpose of this study is to see whether Bell's palsy is associated with serological marker of Herpes Simplex virus type 1, and to study the clinical signs and symptoms manifested by Bell's palsy.

Methodology: This retrospective observational study was carried out in neurology OPD of ShSMCH, Dhaka from June, 2014 to May, 2016. All the patients who came to the OPD were selected as study population. All relevant data, those who fulfill the inclusion criteria were recorded in pre-designed data collection sheet.

Result: A total number of 60 were recruited in this study. 30 were case group and 30 were control group. In our study, more than one quarter of cases (26.7\%) was found between 26-30 years, while lowest age incidence was 16-20 years (6.7\%). More than 37\% of cases had their attack of Bell's palsy in monsoon season, only $3 \%$ in autumn. $52.3 \%$ had pain in or around the ear. Taste abnormalities were found in $23.3 \%$.

Conclusion: From this study, it can be concluded that, Herpes simplex type 1 may be an important causative agent for Bell's palsy. But a large scale study is needed for establishment of Herpes Simplex type 1 as an important infective agent for causation of Bell's palsy.

Keywords: Bell's palsy, Herpes simplex type 1.

\section{INTRODUCTION}

Idiopathic facial paralysis also called Bell's Palsy is one of the commonest condition seen in neurologic practice, accounting for approximately 50 percent of cases of peripheral facial paralysis ${ }^{[1]}$. Bell's Palsy causes consider able functional, psychosocial and aesthetic disturbance to patients.

Histological and clinical evidence suggests that the site of lesion within the confluence of the facial canal, particularly at its medial end ${ }^{[3]}$.

However, most recent studies have shown that herpes simplex virus 1 may be the most likely candidate virus and polymerase chain reaction of endoneurial fluid Herpes simplex virus 1 genome has been identified in more than three quarter of bell's palsy cases, whereas varicella zoster virus or Epstein barr virus have not been found therein ${ }^{[4,5,7,21]}$. Reactivation of herpes simplex virus 1 probably results in the initial facial weakness and virus will become undetectable with recovery ${ }^{[5]}$.

Serum antibody titre to herpes simplex virus is a reliable diagnostic tool for Bell's Palsy ${ }^{7}$. Salivary polymerase chain reaction for herpes simplex virus type 1 is more likely to confirm virus during the replicating phase, but these tests remain research tools. Serological test for Bell's Palsy (IgG, IgM) are essential for diagnosis of Bell's Palsy, where PCR testing is not possible. In our study, we have done serum anti- HSV1 IgM for bell's Palsy cases and control groups. The laboratory diagnostic value ISR (Immune status ratio) $\geq 1.10$ were taken as positive; ISR 0.91-1.09 were considered negative results.

Histological studies of facial nerve during acute stage of Bell's palsy, either at autopsy or during surgery, have shown signs of oedema, 
perivascular perineurial lymphocytic and macrophage infiltration of the nerve, an increase in axon: myelin surface ratio (thinning of myelin) and a decrease in the total fibre count ${ }^{[6]}$. Bell's palsy is equally frequent in men and women (ratio 48:52). This disease occurs on either side of the face and approximately $5 \%$ of the patients will have a recurrent palsy affecting the same or opposite side. Pregnancy, diabetes mellitus and arterial hypertension have all been associated with an increased incidence of Bell's palsy ${ }^{[8,9,10]}$.

\section{OBJECTIVES}

\subsection{General}

a) To determine the association of Herpes simplex virus 1 infection in Bell's palsy cases.

b) To find out important aetiological factors in relation to Bell's palsy

c) To study the clinical signs and symptoms manifested by the patients of Bell's palsy.

\subsection{Specific}

a) To see whether Bell's palsy is associated with the presence of serological marker of Herpes simplex virus type 1

\section{Materials ANd Methods}

\subsection{Type of Study}

This is a retrospective observational study.

\subsection{Place of Study}

This study was carried out in Neurology outpatient department (NOPD), Shaheed Suhrawardy Medical College Hospital (ShSMCH), Dhaka.

\subsection{Period of Study}

This study was carried out from June 2014 to May 2016.

\section{- Study Objects}

- Study Population

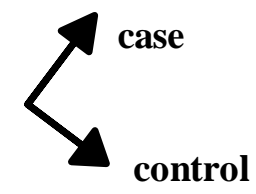

- Case: Subjects who satisfied the following inclusion and exclusion criteria.

\subsection{Inclusion Criteria for Cases}

a) Flaccid paresis of all the muscles of face on the involved side

b) Affected side is smooth and brow droops, but palpebral fissure is widened.

c) Angle of mouth is depressed

ARC Journal of Journal of Cancer Science d) Cheeks balloons on expiration

e) Dysarthria, drooling of saliva

f) Food collected between the gum and the cheeks

g) Lid remains open (lagophthalmos).

h) Lower lid is everted with excessive tearing (epiphora).

i) Bell's phenomenon -On attempted to closure of eye globe turns up and out.

j) Perversion of taste and hyperacusis

k) Various facial reflexes are lost.

1) Those cases of Bell's palsy who came within two weeks of onset of attack.

\subsection{Exclusion criteria for cases}

a) History of trauma

b) Gradual evolution over several weeks

c) Persistence of severe symptoms for longer than 3 months

d) Vesicular eruption on external ear, pinna of ear, base of the tongue or soft palate

e) Slowly progressive facial paralysis

f) Pain, hearing loss in association with facial paralysis

g) Involvement of lower cranial nerves in association with CN VII lesion

h) Recurrent facial nerve lesion

i) Any form of treatment received for the disease before attending at neurology OPD, ShSMCH

\section{Control Selection}

Control: Normal healthy people who came with patients and satisfy following inclusion criteria were taken as control.

All the patients were medically stable, mentally sound without any features of other systemic diseases like diabetes, leukemia, sarcoidosis, Lyme diseases and neoplasm. Other than facial nerve all the patients had no evidence of other neurological signs. In a non-directed fashion, each of the patients was assessed by a standard questionnaire.

All the patients were asked about any treatment they received before coming to us like any homeopathic or ayurvedic medication or any history of toxic exposure. After getting the negative answers, they were included in the study group.

Page | 19 


\section{Data Collection}

All relevant data were recorded in a predesigned data collection sheet which included -

a) history taking with particular aspects relevant to this study

b) general examination

c) neurological examination. Viral antibody was detected by ELISA method.

Three cc of blood was collected into plain test tube, avoiding haemolysis, mixed by inverting sample tube several times and left to clot for one hour at room temperature $\left(18^{\circ}-28^{\circ} \mathrm{C}\right)$ and protected from direct light. Serum samples were stored at $-17^{\circ} \mathrm{C}$ or lower if not assayed on the same day. Blood was collected between the 7-15 days of illness. The patient's ISR (Immune Status ratio) values are interpreted as follows:

$\leq 0.90$ is negative: i.e. No significant level of detectable IgM antibody to HSV.

0.91-1.09 is equivocal: i.e. samples should be retested.

$\geq 1.10$ is positive: i.e. significant level of detectable IgM antibody to HSV-1, that's Indicative of current or recent infection.

\section{DATA ANALYSiS}

Data were analyzed using SPSS version 11.5 (Statistical Package for Social Sciences). The test statistics used analyze the data were descriptive statistics, Chi-square, Fisher's Exact Probability Test and Student's t-test.

\subsection{Demographic Profile}

\begin{tabular}{|c|c|c|c|}
\hline \multirow{2}{*}{$\begin{array}{l}\text { Age of the } \\
\text { patient (years) }\end{array}$} & \multicolumn{2}{|l|}{ Group } & \multirow{2}{*}{$\begin{array}{l}\mathrm{P}- \\
\text { values }\end{array}$} \\
\hline & $\begin{array}{l}\text { Case } \\
(\mathrm{n}=30)\end{array}$ & $\begin{array}{l}\text { Control } \\
(\mathrm{n}=30)\end{array}$ & \\
\hline$\leq 15$ & $6(20.0)^{*}$ & $1(3.3)$ & \multirow[t]{6}{*}{0.290} \\
\hline $16-20$ & $2(6.7)$ & $4(13.3)$ & \\
\hline $21-25$ & $7(23.3)$ & $4(13.3)$ & \\
\hline $26-30$ & $8(26.7)$ & $6(20.0)$ & \\
\hline$>30$ & $7(23.3)$ & $15(50.0)$ & \\
\hline Mean \pm SEM & $\begin{array}{ll}23.83 & \pm \\
1.37 & \end{array}$ & $\begin{array}{l}25.90 \quad \pm \\
1.37\end{array}$ & \\
\hline
\end{tabular}

*Figures in the parentheses indicate corresponding percentage $\%$

**Student's t-test was done to analyze the data and the level of significance was 0.05 .

\subsection{Clinical Presentation}

\begin{tabular}{|c|c|}
\hline Symptoms & $\begin{array}{c}\text { Number of occurrence } \\
\text { /Percentage }(\mathrm{n}=30)\end{array}$ \\
\hline $\begin{array}{c}\text { Pain in and around the } \\
\text { ear }\end{array}$ & $16(53.3 \%)$ \\
\hline Taste abnormalities & $07(23.3 \%)$ \\
\hline Facial tingling & $63 \%$ \\
\hline
\end{tabular}

\begin{tabular}{|c|c|}
\hline Neck pain & $17(56.7 \%)$ \\
\hline Hearing problem & $13 \%$ \\
\hline Blurred vision & $12(40 \%)$ \\
\hline Involved side & Left $=53 \%$, Right $=$ \\
& $47 \%$ \\
\hline
\end{tabular}

6.3. Distribution of Cases by Season of Occurrence $(\mathrm{N}=30)$

\begin{tabular}{|c|c|}
\hline Seasons & Percentage \\
\hline Winter & $10 \%$ \\
\hline Spring & $10 \%$ \\
\hline Summer & $33 \%$ \\
\hline Monsoon & $37 \%$ \\
\hline Autumn & $3 \%$ \\
\hline Post-autumn & $7 \%$ \\
\hline
\end{tabular}

\subsection{Comparison of Paraclinical Parameters between Case and Control}

\begin{tabular}{|c|c|c|c|}
\hline \multirow{2}{*}{$\begin{array}{l}\text { Paraclinical } \\
\text { Parameters }^{\#}\end{array}$} & \multicolumn{2}{|l|}{ Group } & \multirow[t]{2}{*}{ P-values* } \\
\hline & $\begin{array}{l}\text { Group A } \\
(n=30)\end{array}$ & $\begin{array}{l}\text { Group B } \\
(\mathrm{n}=30)\end{array}$ & \\
\hline $\mathrm{RBS}(\mathrm{mg} / \mathrm{dl})$ & $\begin{array}{l}110.4 \\
\pm 1.62\end{array}$ & $\begin{array}{l}117.5 \pm \\
2.21\end{array}$ & 0.012 \\
\hline $\begin{array}{l}\text { WBC (per cu } \\
\text { mm of } \\
\text { blood) }\end{array}$ & $\begin{array}{l}8600 \\
\pm 187\end{array}$ & $\begin{array}{l}5800 \\
\pm 425\end{array}$ & $<0.001$ \\
\hline $\begin{array}{l}\text { Lymphocytes } \\
(\%)\end{array}$ & $41 \pm 1$ & $30 \pm 1$ & $<0.001$ \\
\hline $\begin{array}{l}\text { Neutrophil } \\
(\%)\end{array}$ & $52 \pm 1$ & $65 \pm 1$ & $<0.001$ \\
\hline
\end{tabular}

\#Data were analyzed using students' $t$-test and values were expressed as Mean \pm SEM

*level of significance was 0.05 and $p<0.05$ was considered significant

\subsection{Association between Serum Anti-HSV1 Igm in Bell's Palsy}

\begin{tabular}{|l|l|l|l|}
\hline \multirow{2}{*}{$\begin{array}{l}\text { Serum } \\
\text { anti- } \\
\text { HSV1 }\end{array}$} & \multicolumn{2}{|c|}{ Group } & p-value* \\
\cline { 2 - 3 } $\begin{array}{l}\text { IgM } \\
\text { (ISR) }\end{array}$ & $\begin{array}{l}\text { Case } \\
(\mathrm{n}=30)\end{array}$ & $\begin{array}{l}\text { Control } \\
(\mathrm{n}=30)\end{array}$ & \\
\hline $\begin{array}{l}\text { +ve } \\
(\geq 1.10)\end{array}$ & $01(3.3)$ & 00 & $<0.001$ \\
\hline $\begin{array}{l}\text {-ve } \\
(\leq 0.90)\end{array}$ & $29(96.7)$ & $30(100)$ & \\
\hline $\begin{array}{l}\text { Equivocal } \\
(0.91\end{array}$ & 00 & 00 & \\
$1.09)$ & & & \\
\hline $\begin{array}{l}\text { Mean } \\
\text { anti- }\end{array}$ & 0.46 & $0.12 \pm 0.02$ & \\
HSV1 & \pm 0.02 & & \\
IgM & & & \\
\hline
\end{tabular}

\# ISR means Immune Status Ratio: Data pertaining was analyzed using Student's t-test and values were expressed as Mean SEM

* level of significance was 0.05 and $p<0.05$ was considered significant 


\section{DISCUSSION}

This was a retrospective observational study, which included 60 subjects. Among the study population 30 were in case group with Bell's palsy and another 30 were in control group without Bell's palsy. The study was carried out to see whether Anti-HSV type 1 IgM has any association with Bell's palsy or not. ELISA method was used to detect the presence of AntiHSV type 1 Antibody (IgM) in blood samples of both groups.

Bell's palsy can occur in any age group. In our study more than one-quarter of case $(26.7 \%)$ was found between 26-30 years, while in lowest age incidence was found between 16-20 years of age $(6.7 \%)^{[2,11,12,13]}$.

In our study females are affected a bit higher $(56.5 \%)$ in compared to male group $(43.3 \%)$. So our study showed that females were affected more than males. It does not coincide with the study group that showed no difference in incidence between the sexes ${ }^{[2,13,14,15,16,17]}$.

In respect to seasonal occurrence more than $37 \%$ of cases at their attack of Bell's palsy in the monsoon season, only $3 \%$ in autumn ${ }^{[2,16,18]}$.

Among the clinical features $53.3 \%$ had pain in or around the ear. Taste abnormalities were found in only $23.3 \%$ cases ${ }^{[19,20]}$.

Finally in our study the association between serum Anti-HSV1 IgM level and Bell's palsy, in $1(3.3 \%)$ case was found to be positive for serum Anti-HSV1 IgM of cases were more than 3 times higher $(0.46 \pm 0.02)$ than that of controls $(0.12 \pm 0.02) \quad(\mathrm{P}<0.01)$. Though this result is statistically significant but immunologically only one of the cases the titre level was found to be positive (ISR $\geq 1.10$ ) and rest 29 cases and 30 control patients had immunologically insignificant titre i.e. titre result is negative. This statistical significance is due to inclusion of negative results of cases that has no immunological significance. So this statistical significance is not so important in this study.

\section{SUMmaRY}

Serum Anti-HSV 1 Antibody (IgM) was detected by ELISA method in both control and case groups. Immunologically significant titre was found in only one case (ISR $\geq 1.10$ ) but rest of the 29 cases had immunologically had immunologically insignificant titre (results were negative). The mean Anti HSV-1 IgM of cases was about three times higher than that of controls $(\mathrm{P}<0.001)$. So this result is statistically significant as because negative values were also considered same as positive values, but actually negative values had not such importance as positive values.

\section{CONCLUSION}

From this study it can be concluded that herpes simplex type 1 may be an important causative agent for Bell's palsy. But a large scale study is needed for establishment of herpes simplex type 1 as an important infective agent for causation of Bell's palsy.

\section{REFERENCES}

[1] Brewis M, Proskanzer DC, Rolland C, Miller H (1996). Neurologic disease in an English Community. ActaNeurologicaScand 42:9-89

[2] Katusic SK, Beard CM, Wiederholt WC, Bergstralh EJ, Kurland LT: Incidence, clinical features, and prognosis in Bell's palsy, Rochester, Minnesota, 1968-1982. Ann Neurol 1986;20:622-7

[3] Adour KK, Byl FM, Hilsinger RLJ, Kahn ZM, Sheldon MI: The true nature of Bell's palsy: Analysis of 1000 consecutive patients. Laryngoscope 1978;88:787-73

[4] Furuta Y, Fukuda S, Chida E, Takasu T, Ohtani $F$, Inuyama Yet al. Reactivation of Herpes Simplex virus type 1 patients with Bell's palsy. J Med Virol 1998; 54: 162-6

[5] Murakami S, HatoN,Mizobuchi M. Role of Herpes simplex infection in the pathogenesis of facial paralysis in mice. Ann Otol Rhino Laryngol 1996; 105:49-53

[6] Adour KK, Current concepts in Neurology; Diagnosis and management of facial paralysis; N. Engl. J. Med 1982; 307:348-51

[7] Marra CM (1999) Bell's palsy and HSV-1 infection. Muscle Nerve 22:1476-8

[8] Devriese PP, Schumacher T, Scheide A. (1990) Incidence, prognosis and recovery of Bell's palsy. A Survey of about 1000 patients (19741983). ClinOtolaryngol 15:15-27

[9] Qui WW, Yin SS, Tucker FJ, Aarstad RF, Nguyen HH. Time course of Bell's palsy. Arch Otolaryngol Head neck Surg. 1996; 122:967-72

[10] Roggenkamper P, Laskawi R, Danenz W (1994): Orbicular synkinesis after facial paralysis. Doc. Ophthalmol 86:395-402

[11] Alter M (1963). Familial aggregation of Bell's palsy. Arch neurol 8:557-64

[12] Presley AP (1978). Familial Bell's palsy. J Royal College General Practitioners 28:752-3

[13] Yanagihara N, Yumoto E, Shibahara T (1998). Familial bell's palsy: Analysis of 25 families. Ann OtolRhinolLaryngol 97:8-10 
[14] Gregg G (1961). Some observations on Bell's palsy in Belfast during the period 1949 to 1958. Arch Phys Med Rehabilitaion 20:622-7

[15] Melotte G (1961) Mizobuchi M, Nakashiro Y, Doi T, Hato N, Yanagihara N (1996). Bell's palsy and Herpes Simplex virus: Identification of viral DNA in endoneurial fluid and muscle. Ann Intern Med 124:27-30

[16] Mair IWS, De Graaf AS (1974). Peripheral facial palsy in subarctic Norway. ActaOtolaryngologica 77:119-25

[17] De Diego JI, Prim MP, Madero R, Gavilan J (1999). Seasonal patterns of idiopathic facial paralysis: a 16-year study. Otolaryngology Head Neck Surg 120:269-71
[18] Brandenburg NA, Annegers JF (1993). Incidence and risk factors for bell's palsy in Laredo, Texas: 1974-1982. Neuroepidemiology 12:313-25

[19] Imarhiagbe D, Prodinger W, Schmutzhard E (1993) InfektionserrgeralsmoglicheUrasche der idiopathischenFacialisparese. WrKlinWschr 105:611-3

[20] May M, Klein SR, Blumenthal F, Evoked electromyography and idiopathic facial paralysis. Otolaryngol Head neck Surg 1983; 91:678-85

[21] McComick DP. Herpes Simplex virus as a cause of Bell's palsy. Lancet 1972;1:937-9

Citation: Islam M M, Sarkar S, Das P C, Rahman T, Sazib SMF, Association Between Herpes Simplex Type 1 Virus Infection And Bell's Palsy. ARC Journal of Cancer Science. 2017; 3(1):18-22. doi:dx.doi.org/10.20431/ 2455-6009.0301003.

Copyright: (c) 2017 Authors. This is an open-access article distributed under the terms of the Creative Commons Attribution License, which permits unrestricted use, distribution, and reproduction in any medium, provided the original author and source are credited. 